\title{
Isolation and Characterization of the DNA-dependent RNA Polymerase of Rhizobium leguminosarum 300
}

\author{
By W. LOTZ, ${ }^{1 *}$ H. FEES, ${ }^{1}$ W. WOHLLEBEN ${ }^{2}$ AND H. J. BURKARDT ${ }^{1}$ \\ ${ }^{1}$ Institut für Mikrobiologie und Biochemie, Lehrstuhl für Mikrobiologie, Universität \\ Erlangen-Nürnberg, D-8520 Erlangen, F.R.G. \\ ${ }^{2}$ Lehrstuhl für Genetik, Biologie VI, Universität Bielefeld, D-4800 Bielefeld, F.R.G
}

(Received 17 October 1980; revised 19 December 1980)

\begin{abstract}
The DNA-dependent RNA polymerase isolated from Rhizobium leguminosarum 300 contains the following subunits: $\beta^{\prime}, \beta$, polypeptide $A$ and $\alpha$ (molecular weights 149000 , 146000,93000 and 42000 , respectively). Polypeptide $A$ is postulated to be the $\sigma$ factor of the enzyme. The experimental conditions used for the in vitro assay of the enzyme activity, with plasmid pMB9 as template, included: $40 \mathrm{mM}-\mathrm{Tris} / \mathrm{HCl}(\mathrm{pH} 7.9), 150 \mathrm{mM}-\mathrm{NaCl}, 5 \mathrm{mM}$ $\mathrm{MgCl}_{2}$, at $34^{\circ} \mathrm{C}$. The isolated enzyme was shown by electron microscopy to bind specifically to the region of early promoters of DNA of the Escherichia coli bacteriophage T7. Therefore, Rhizobium-specific promoters may have base sequences in common with those of $E$. coli.
\end{abstract}

\section{INTRODUCTION}

The transcription of DNA by the DNA-dependent RNA polymerase from Escherichia coli and from other bacterial species has been extensively studied (see Burgess, 1976; Chamberlin, 1976). Within the family Rhizobiaceae only the RNA polymerase of Agrobacterium tumefaciens has been described (Knopf, 1974), and little is known about transcription in bacteria of the genus Rhizobium.

Rhizobia can nodulate Leguminosae and fix $\mathrm{N}_{2}$ symbiotically as bacteroids (see Vincent, 1977). In the case of rhizobia nodulating Lotus species (Pankhurst, 1977) and of Rhizobium leguminosarum (Pain, 1979), a significant fraction of mutants resistant to rifampicin have lost the ability to fix $\mathrm{N}_{2}$. Rifampicin is known to inhibit bacterial transcription (Benveniste \& Davies, 1973). In E. coli (Rabussay \& Zillig, 1969) and Bacillus subtilis (Linn et al., 1975) mutations to rifampicin resistance affect the $\beta$ subunit of the RNA polymerase. Genetic studies of rifampicin-resistant mutants of $B$. subtilis that are unable to sporulate have indicated that the RNA polymerase may have a regulatory function in spore differentiation (see Losick \& Pero, 1976). It is therefore possible that the RNA polymerase of Rhizobium may play a significant role in the regulation of differentiation of $\mathrm{N}_{2}$-fixing bacteroids.

In this paper, we report the isolation and characterization of the RNA polymerase from vegetative cells of the wild-type $R$. leguminosarum strain 300 (Johnston \& Beringer, 1975) using a method adapted from that of Burgess \& Jendrisak (1975). This procedure includes the precipitation of the RNA polymerase from cell extracts by Polymin P, as described by Zillig et al. $(1970 b)$, a DNA affinity chromatography step, and a sizing step by Bio-Gel A5m chromatography. The subunit pattern of the isolated enzyme is compared with that of the RNA polymerase of $E$. coli and of $A$. tumefaciens. In addition, the promoter-specific DNA-binding of the enzyme, and experimental conditions for in vitro transcription assays, are described. 


\section{METHODS}

Bacterial strains and growth. The wild-type Rhizobium leguminosarum strain 300 (Johnston \& Beringer, 1975) was provided by Dr J. E. Beringer (John Innes Institute, Norwich) and Escherichia coli K 12 strain GM4 by Dr F. C. Cannon (ARC Unit of Nitrogen Fixation, Sussex). The latter strain carries plasmid pSA31 which originated from plasmid pBR322 (F. C. Cannon, personal communication) by the insertion of the Klebsiella pneumoniae genes $n i f H$ and nifD between the EcoRI and BamHI cuts of pBR322. Escherichia coli strain HB101(pMB9) was provided by Professor A. Pühler (Institut für Genetik, Universität Bielefeld, F.R.G.).

Rhizobium leguminosarum 300 was routinely grown at $29^{\circ} \mathrm{C}$ in liquid TY medium (Beringer, 1974) or B + Y medium (Van Brussel et al., 1977). The organism was stored at $-20^{\circ} \mathrm{C}$ after mixing $1 \mathrm{ml}$ of overnight culture (in TY medium) with $1 \mathrm{ml} 90 \%(\mathrm{v} / \mathrm{v})$ glycerol, or on TY agar plates which were transferred weekly. Nodulation tests with garden peas (Vincent, 1970) and acetylene reduction assays (using a Hewlett-Packard gas chromatograph) were done about every 2 months.

For the isolation of the RNA polymerase, bacteria were grown under aeration in a 70 litre fermenter (Chemap, Zürich, Switzerland) in B + Y medium. The cells were harvested in the late-exponential phase of growth with a Padberg flow-through centrifuge, then frozen in liquid nitrogen and stored at $-25^{\circ} \mathrm{C}$. The purity of all fermenter cultures was routinely checked on nutrient agar plates Icontaining $0.8 \%(\mathrm{w} / \mathrm{v})$ Difco nutrient broth and $1.5 \%(\mathrm{w} / \mathrm{v})$ Difco agarl and by sensitivity to $R$. leguminosarum bacteriophage RL-4 (obtained from $\mathrm{Dr} \mathrm{J}$. E. Beringer).

Buffers. TGED buffer, grinding buffer and storage buffer were described by Burgess \& Jendrisak (1975). TGED/PMSF buffer contained phenylmethanesulphonyl fluoride (PMSF; from Serva) at $23 \mu \mathrm{g} \mathrm{ml}^{-1}$. To enhance lysis of $R$. leguminosarum 300 the modified grinding buffer contained: $0.05 \mathrm{M}$-Tris $/ \mathrm{HCl}(\mathrm{pH} 7.9) ; 0.05 \mathrm{M}$-EDTA

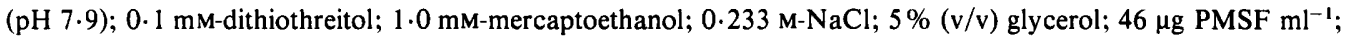
$1 \mathrm{mg}$ lysozyme $\mathrm{ml}^{-1}$. The incubation buffer for DNA/RNA polymerase binding assays was that of Portmann et al. (1974).

Plasmid and phage DNA. Plasmids pMB9 (Rodriguez et al., 1976) and pSA31 were isolated from E. coli HB 101 (pMB9) and E. coli GM4(pSA31), respectively, by the method of Guerry et al. (1973). At least $80 \%$ of the plasmids in these preparations were covalently closed circles as shown on $1 \%(\mathrm{w} / \mathrm{v})$ agarose gels. The DNA of $E$. coli bacteriophage T7 was a gift from Dr R. Lurz (Max-Planck-Institut für Molekulare Genetik, Berlin-Dahlem, F.R.G.).

Sodium dodecyl sulphate-polyacrylamide gel electrophoresis (SDS-PAGE). This was carried out as described by Laemmli (1970) on a BioRad model 221 apparatus for plate gels. Staining and destaining of the gels was as described by Burgess \& Jendrisak (1975). The molecular weights of the RNA polymerase subunits of $R$. leguminosarum 300 were determined (Dunker \& Rueckert, 1969; Weber \& Osborn, 1969) by comparison with the SDS-PAGE molecular weight standards from BioRad (range 14300 to 200000). In addition, purified RNA polymerase from $E$. coli was run in the same gel; the molecular weights of its subunits were taken as $\beta^{\prime}=$ $150000, \beta=145000$ (Berg et al., 1971), $\sigma=85000$ and $\alpha=40000$ (Zillig et al., 1970a).

DNA-Sepharose $2 B$ column. Sepharose 2B-300 (Sigma) was activated and coupled to DNA as described by Arndt-Jovin et al. (1975). A column of $90 \mathrm{ml}$ bed volume, containing about $90 \mathrm{mg}$ coupled calf thymus DNA (Serva), was used.

Isolation of RNA polymerase from $R$. leguminosarum 300. The isolation procedure was adapted from that of Burgess \& Jendrisak (1975). All six steps of the following procedure were carried out in the cold room $\left(4\right.$ to $\left.6{ }^{\circ} \mathrm{C}\right)$ unless otherwise stated.

Step 1: Cell disruption and enzyme extraction. Cells grown in B + Y medium were used for the isolation of RNA polymerase, since these cells were more sensitive to lysozyme than those grown in TY medium. Frozen cells $(100 \mathrm{~g})$ were partially thawed, then placed in a 1 litre Waring blender with $300 \mathrm{ml}$ ice-cold grinding buffer and blended for about $5 \mathrm{~min}$ at low speed; the resulting suspension was left at 2 to $5^{\circ} \mathrm{C}$ for $2 \mathrm{~h}$. Then $7 \mathrm{ml} 4 \%(\mathrm{w} / \mathrm{v})$ sodium deoxycholate (Merck) was added, the mixture was blended at low speed and left for $40 \mathrm{~min}$ at room temperature with occasional stirring. During this period the temperature rose to about $7^{\circ} \mathrm{C}$ and, due to cell lysis, the viscosity of the mixture increased. The lysate was placed on ice for $10 \mathrm{~min}$, and then blended at high speed for $30 \mathrm{~s}$. After addition of $400 \mathrm{ml}$ TGED/PMSF buffer containing $0.2 \mathrm{M}-\mathrm{NaCl}$ the lysate was blended at high speed for $30 \mathrm{~s}$ and then centrifuged $(6200 \mathrm{~g}, 45 \mathrm{~min})$ in $250 \mathrm{ml}$ polycarbonate bottles in a Sorvall RC5-B centrifuge. The resulting supernatant $(735 \mathrm{ml}$ ) was kept on ice; the pellet (about $46 \mathrm{~g}$ ) was discarded.

Step 2: Polymin P precipitation. Polymin P precipitation was performed essentially as described by Burgess \& Jendrisak (1975) for the isolation of E. coli RNA polymerase. Polymin P was a gift of BASF, Ludwigshafen, F.R.G. A $26.7 \mathrm{ml}$ volume of $10 \%(\mathrm{v} / \mathrm{v}$ ) ice-cold Polymin P (pH 7.9) was added slowly with stirring to the $735 \mathrm{ml}$ supernatant from step 1. Slow stirring on ice was continued for $5 \mathrm{~min}$. The precipitate was then sedimented by centrifugation $(3500 \mathrm{~g}, 15 \mathrm{~min}$ ). Analysis by SDS-PAGE (not shown) indicated that there was a preferential enrichment of RNA polymerase protein in the precipitate, as judged from the appearance of bands in the chromatogram which probably corresponded to the $\beta^{\prime} \beta$ subunits of the RNA polymerase (see below). 
Step 3: $0.5 \mathrm{M}-\mathrm{NaCl}$ wash and $1.0 \mathrm{M}-\mathrm{NaCl}$ elution of the Polymin $\mathrm{P}$ precipitate. The pellet from step 2 was blended for $10 \mathrm{~min}$ in $400 \mathrm{ml} \mathrm{TGED} / \mathrm{PMSF}$ buffer containing $0.5 \mathrm{M}-\mathrm{NaCl}$ and the centrifuged $(15 \mathrm{~min}, 3500 \mathrm{~g})$. The resulting pellet was blended at low speed in $400 \mathrm{ml}$ TGED buffer containing $1.0 \mathrm{M}-\mathrm{NaCl}$. This procedure led to the extraction of most of the RNA polymerase. The eluate was freed from the precipitate by centrifugation $(3500 \mathrm{~g}, 30 \mathrm{~min})$.

Step 4: Ammonium sulphate precipitation. $\left(\mathrm{NH}_{4}\right)_{2} \mathrm{SO}_{4}(133 \mathrm{~g})$ was added in small portions to the $380 \mathrm{ml}$ eluate from step 3 to give $50 \%$ saturation, $1 \mathrm{M}-\mathrm{NaOH}\left(5 \mu \mathrm{gg}^{-1}\right)$ being added to maintain constant pH (Burgess, $1969 a$ ). The solution was left standing on ice for at least $2 \mathrm{~h}$. The resulting precipitate was sedimented by centrifugation $(8800 \mathrm{~g}, 45 \mathrm{~min})$ and dissolved in $50 \mathrm{ml}$ TGED/PMSF buffer. Then $50 \mathrm{ml}$ TGED/PMSF buffer containing $0.15 \mathrm{M}-\mathrm{NaCl}$ was added and the solution was dialysed $(2 \times 30 \mathrm{~min})$ against 1 litre TGED/PMSF buffer containing $0 \cdot 15 \mathrm{M}-\mathrm{NaCl}$. The conductivity of the solution then corresponded to that of the buffer.

Step 5: DNA-Sepharose affinity chromatography. The dialysed solution from step 4 was loaded on to a DNA-Sepharose 2B column, freshly equilibrated with TGED buffer containing $0.15 \mathrm{M}-\mathrm{NaCl}$, and washed with $500 \mathrm{ml}$ of the same buffer. When the $A_{280}$ of collected fractions had reached a value below 0.01 , a linear salt gradient from 0.15 to $1.0 \mathrm{M}-\mathrm{NaCl}$ (total volume $300 \mathrm{ml}$ ) was applied. During loading, washing and elution of the column, $3 \mathrm{ml}$ fractions were collected at a flow rate of $0.4 \mathrm{ml} \mathrm{min}{ }^{-1}$. Both the $A_{280}$ and the RNA polymerase activity of the fractions were measured. Fractions with maximum activity were pooled and concentrated by ultrafiltration (Amicon concentrator, Diaflo UM10 filter) to a total volume of $1 \mathrm{ml}$.

Step 6: High salt Bio-Gel A5m chromatography. The $1 \mathrm{ml}$ solution from step 5 was loaded on to a Bio-Gel A5m column $(2 \times 55 \mathrm{~cm}$; mesh 200 to 400 , preswollen, from Bio-Rad). The column was run with TGED buffer containing $0.5 \mathrm{M}-\mathrm{NaCl}$ and fractions of $2 \mathrm{ml}$ were collected at a flow rate of $0.14 \mathrm{ml} \mathrm{min}{ }^{-1}$. The $A_{280}$ and the RNA polymerase activity of the fractions were determined. The fractions with maximum RNA polymerase activity were pooled, dialysed against storage buffer and stored at $-20^{\circ} \mathrm{C}$.

RNA polymerase assay. The general RNA polymerase assay conditions were adapted from those of Burgess $(1969 a)$. The standard in vitro transcription assay contained (in a total volume of $100 \mu \mathrm{l}): 40 \mathrm{mM}-\mathrm{Tris} / \mathrm{HCl}$ (pH 7.9); 5 mM- $\mathrm{MgCl}_{2} ; 0.4 \mathrm{~mm}$-potassium phosphate $(\mathrm{pH} 7.5) ; 150 \mathrm{mM}-\mathrm{NaCl} ; 0.1 \mathrm{~mm}-\mathrm{EDTA} ; 0.1 \mathrm{~mm}-$ dithiothreitol; $0.1 \mathrm{mM}$ each of GTP, CTP, ATP, and UTP; $3 \mu \mathrm{Ci}\left[{ }^{3} \mathrm{H}\right] \mathrm{UTP}$ [45 Ci mmol ${ }^{-1}\left(1.665 \mathrm{TBq} \mathrm{mmol}^{-1}\right)$; Amershaml; $3 \mu \mathrm{g}$ pMB9 DNA or $2 \mu \mathrm{g}$ pSA31 DNA; $10 \mu \mathrm{g}$ enzyme. The potassium phosphate was routinely added to inhibit any polynucleotide phosphorylase activity possibly present during some steps of enzyme purification (Burgess, 1969a). Glycerol, which is known to stabilize the RNA polymerase (Burgess, 1976); was not added to the assays because the purified enzyme was stored in buffer containing $50 \%(\mathrm{v} / \mathrm{v}$ ) glycerol (giving a final glycerol concentration in the assay of $5 \%$ ). For the determination of the activity of the isolated RNA polymerase the unlabelled UTP was replaced by $0.1 \mathrm{~mm}^{-}\left[{ }^{3} \mathrm{H}\right] \mathrm{UTP}\left[1 \mathrm{Ci} \mathrm{mmol}^{-1}(37 \mathrm{GBq} \mathrm{mmol})^{-1}\right]$. One unit of RNA polymerase activity is defined as the amount of enzyme required to catalyse the incorporation of $1 \mathrm{nmol}$ UMP into trichloroacetic acid-precipitable material in $10 \mathrm{~min}$.

The in vitro assays (done in duplicate or triplicate) were routinely incubated at $34{ }^{\circ} \mathrm{C}$ for at least $20 \mathrm{~min}$, then chilled on ice and precipitated with $2 \mathrm{ml}$ ice-cold $5 \%(\mathrm{w} / \mathrm{v})$ trichloroacetic acid. After about $10 \mathrm{~min}$ the precipitates were collected on nitrocellulose filters $(0.45 \mu \mathrm{m}$; Sartorius), and washed five times with about $2.5 \mathrm{ml}$ and then once with about $5 \mathrm{ml}$ ice-cold $5 \%$ trichloroacetic acid. The filters were dried under an infrared lamp and counted in a scintillation counter (Beckman LS-230) in $5 \mathrm{ml} \mathrm{Scintimix} \mathrm{(Koch-Light).} \mathrm{In} \mathrm{controls} \mathrm{either} \mathrm{the} \mathrm{DNA} \mathrm{template} \mathrm{or}$ the RNA polymerase was omitted.

RNA polymerase-DNA binding studies. The general methods for the binding of RNA polymerase to DNA were those of Portmann et al. (1974) and Koller et al. (1978). About $25 \mathrm{ng}$ T7 DNA was mixed with $100 \mu$ incubation buffer, then $1 \mu \mathrm{l}$ RNA polymerase solution $\left(2.7 \mathrm{mg} \mathrm{ml}^{-1}\right)$ was added and the sample was incubated at $37^{\circ} \mathrm{C}$ for $10 \mathrm{~min}$. Glutaraldehyde fixation $\left(10 \mathrm{~min}\right.$ at $37^{\circ} \mathrm{C}$ ) was done by adding $20 \mu \mathrm{l} 0.5 \%(\mathrm{v} / \mathrm{v})$ glutaraldehyde freshly prepared in 20-fold diluted incubation buffer. The fixed sample was spotted on to the surface of a clean plastic Petri dish and the droplet was touched with a piece of freshly cleaved mica. The mica was washed twice by touching droplets of double-distilled water, and the sample was stained by floating for $30 \mathrm{~s}$ on $1 \%(\mathrm{w} / \mathrm{v})$ uranyl acetate. After two additional washings, the sample was dehydrated stepwise in $50 \%$ and $90 \%(\mathrm{v} / \mathrm{v})$ ethanol. The air-dried mica was rotary shadowed with platinum/iridium $(80: 20)$ at an angle of $5.5^{\circ}$ and covered with a carbon layer by carbon casting using carbon rods pretreated with $0.5 \mathrm{M}-\mathrm{NaCl}$. The carbon film was floated on to a water surface and parts were collected with copper grids.

Electron micrographs were taken with a Philips EM400 electron microscope at a magnification of 3500 . Determinations of the sites of RNA polymerase binding and measurements of T7 DNA lengths were made with a Brühl LMl digitizer at a final magnification of 50800 . The computerized evaluation method of Burkardt et al. (1980) was used with the following modifications: the resolution power of the program was $0.5 \%$ of the total DNA length, and the RNA polymerase molecules on the DNA were enlarged mathematically to a size of $1 \%$ total DNA length. A total of 60 molecules of T7 DNA with bound $R$. leguminosarum 300 RNA polymerase were analysed by this method. 


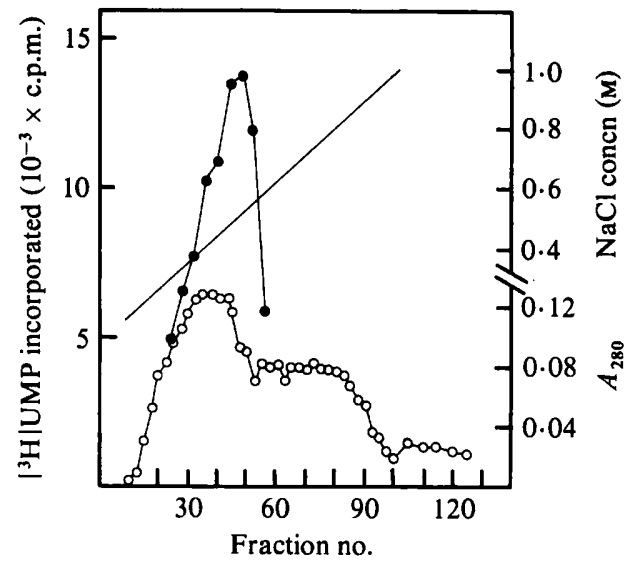

Fig. 1

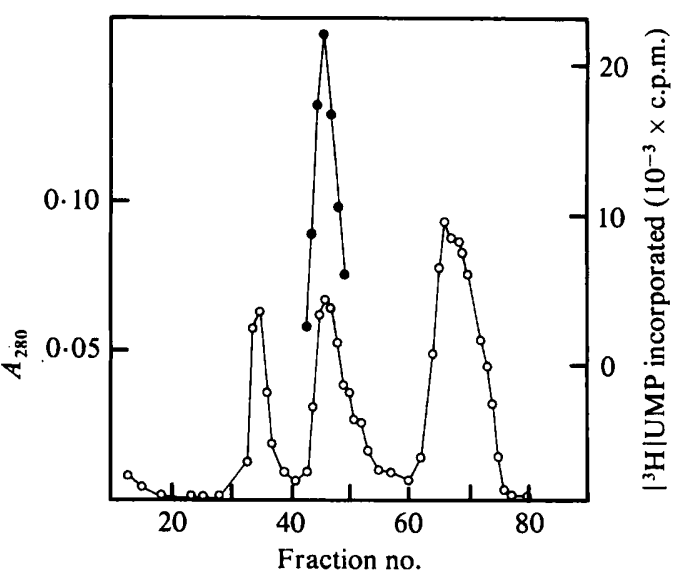

Fig. 2

Fig. 1. Isolation of RNA polymerase from $R$. leguminosarum 300 by DNA-Sepharose 2B chromatography: $O$, absorbance at $280 \mathrm{~nm} ; \mathrm{O}^{-}$, RNA polymerase activity;,$- \mathrm{NaCl}$ concentration.

Fig. 2. Purification of RNA polymerase from $R$. leguminosarum 300 by Bio-Gel A5m chromatography:

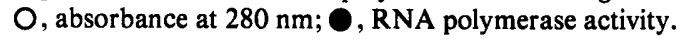

\section{RESULTS AND DISCUSSION}

\section{Isolation of the RNA polymerase from $R$. leguminosarum 300}

The maximum RNA polymerase activity was found in fractions 30 to 55 of the eluate from the DNA-Sepharose 2B column (Fig. 1). Fractions 35 to 54 were pooled, concentrated to $1 \mathrm{ml}$ by ultrafiltration, and then loaded on to a Bio-Gel A5m column. The $A_{280}$ profile of fractions from this column showed three prominent peaks (Fig. 2). Only fractions 43 to 49 , corresponding to the middle peak, showed significant RNA polymerase activity.

The polypeptides present in this peak were analysed by SDS-PAGE on $10 \%$ gels (Fig. 3). Fractions 44 to 51 showed bands in the molecular weight range of the $\beta^{\prime}$ and $\beta$ subunits of the RNA polymerase from $E$. coli, which was run in the same gel. Fractions 44 to 55 contained a polypeptide with a molecular weight somewhat higher than that of the $\alpha$ subunit of the $E$. coli RNA polymerase. Two other major bands were visible in the gel - A (present in fractions 44 to 48 ) and B (in fractions 49 to 55). The molecular weight of the A polypeptide was somewhat higher, and that of the B polypeptide somewhat lower, than the $\sigma$ factor of the $E$. coli RNA polymerase. The three fractions with maximum RNA polymerase activity $(45,46$ and 47) were pooled, dialysed against storage buffer and then stored at $-20^{\circ} \mathrm{C}$.

From the subunit pattern obtained with SDS-PAGE (Figs 3 and 4) the RNA polymerase was judged to be about $95 \%$ pure. The yield of the enzyme was relatively low [ $1 \mathrm{mg}(100 \mathrm{~g}$ cells) ${ }^{-1}$; activity 310 units $\mathrm{mg}^{-1}$. Using the same isolation procedure, we obtained an 18-fold higher yield of RNA polymerase from E. coli (not shown). Rhizobium leguminosarum 300 is much more refractory to lysis than $E$. coli, regardless of the method applied (e.g. cell grinding with aluminium oxide, treatment with ultrasound, or washing with TGED buffer containing $0.2 \mathrm{M}$-EDTA before the lysozyme/deoxycholate treatment). We conclude that the main reason for the relatively low yield of RNA polymerase from $R$. leguminosarum 300 was due to the difficulty in obtaining optimal cell lysis and enzyme extraction.

\section{Subunits of the RNA polymerase}

The isolated RNA polymerase from $R$. leguminosarum 300 was characterized by SDS-PAGE on $10 \%$ gels using the RNA polymerase from $E$. coli as a reference (Fig. 4). The polypeptide corresponding to band $\mathrm{B}$ in Fig. 3 was removed by the Bio-Gel A5m 
Fraction no.

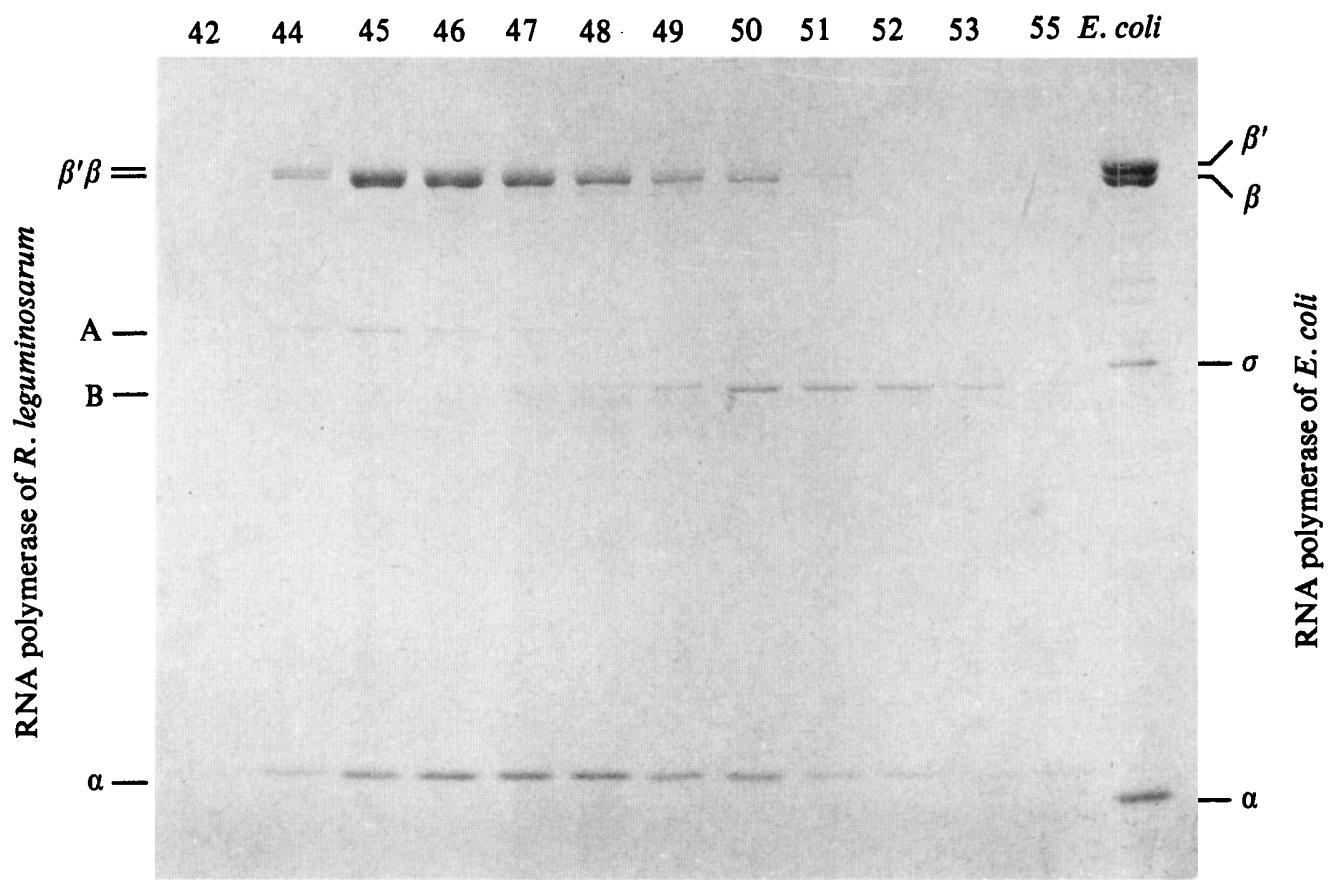

Fig. 3. SDS-polyacrylamide gel after electrophoresis of fractions from the Bio-Gel A5m column of Fig. 2. Samples of $10 \mu \mathrm{l}$ from fractions 42 to 55 , which contained the maximum of RNA polymerase activity, were applied to the gel.

chromatography and was probably a contaminating polypeptide. The molecular weights of the two largest subunits of the RNA polymerase were determined as 149000 and 146000 . These two polypeptides correspond to the $\beta^{\prime}$ and $\beta$ subunits of the $E$. coli RNA polymerase (molecular weights 150000 and 145000, respectively; Berg et al., '1971). Separation of the two large subunits of the rhizobial enzyme could only be demonstrated when relatively low concentrations of RNA polymerase were applied to a gel; at higher enzyme concentrations both subunits tended to run as one band (compare Fig. 3, fractions 44 and 45; and Fig. 4, lanes $b$ and $c$ ), probably because of the relatively small difference in molecular weight.

It remains to be determined which of the two large subunits of the isolated enzyme corresponds to ' $\beta$ '. By defintiion, the subunit responsible for the rifampicin sensitivity of the RNA polymerase is named ' $\beta$ ' (Burgess, 1976). Preliminary in vitro experiments have shown that the RNA polymerase from $R$. leguminosarum 300 is rifampicin-sensitive, in agreement with the in vivo rifampicin sensivitity of $R$. leguminosarum (Johnston \& Beringer, 1975).

The band in Fig. 4 corresponding to the $\alpha$ subunit of the rhizobial RNA polymerase has a higher molecular weight (42000) than that of the $\alpha$ subunit of the $E$. coli RNA polymerase [determined as 39000 by Burgess $(1969 b)$ and 40000 by Zillig et al. (1970a)].

The molecular weight of polypeptide $A$ of the $R$. leguminosarum RNA polymerase was 93000 (based on a molecular weight of 85000 for the $\sigma$ factor of the $E$. coli enzyme; Zillig $e t$ al., $1970 a$ ). We postulate that polypeptide A, which was present in the enzymically active fractions (44 to 48) of the Bio-Gel A5m column, is the $\sigma$ factor of the $R$. leguminosarum 300 RNA polymerase. Its molecular weight is similar to that of the postulated $\sigma$ factor of the RNA polymerase from $A$. tumefaciens $\left(\chi_{1}=98000\right.$; Knopf, 1974).

The ratio of holoenzyme to core enzyme without $\sigma$ was not determined. In comparison to the bands corresponding to the $\beta^{\prime}$ and $\beta$ subunits of the $R$. leguminosarum RNA polymerase, band $\mathrm{A}$ was relatively wèak and therefore the enzyme preparation must also contain a 


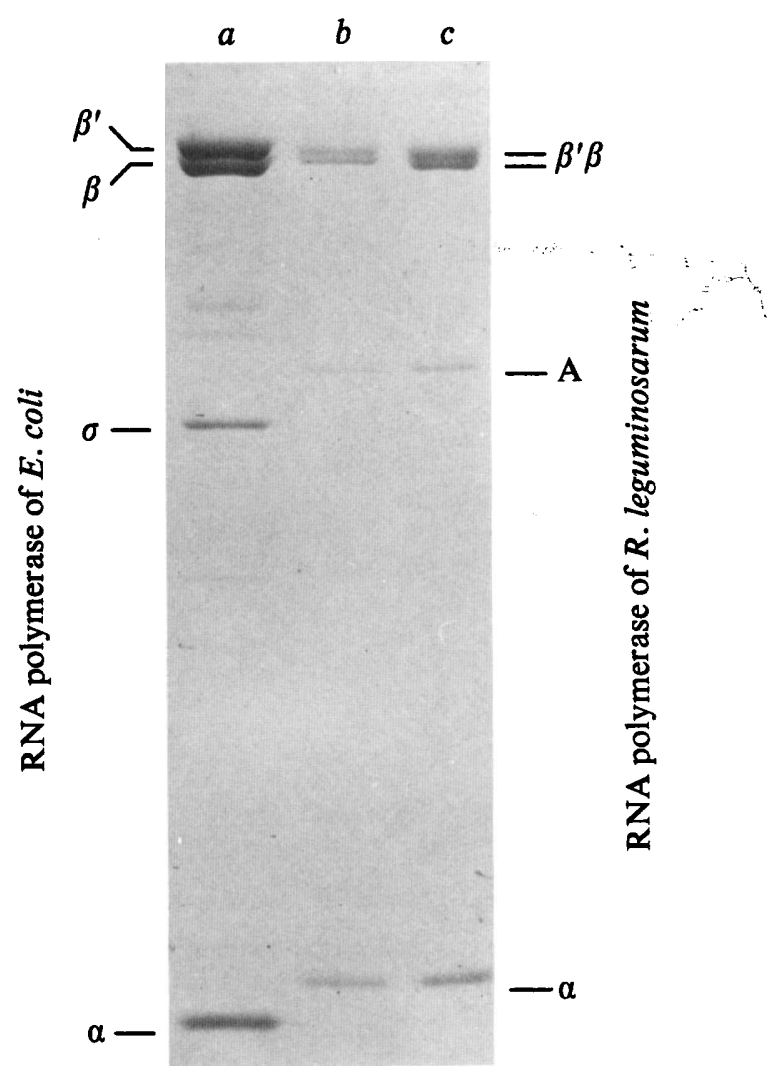

Fig. 4. SDS-polyacrylamide gel after electrophoresis of RNA polymerase from $E$. coli $(a, 5 \mu \mathrm{g})$ and from $R$. leguminosarum $300(b, 1 \mu \mathrm{g} ; c, 2 \mu \mathrm{g})$ after purification by Bio-Gel A5m chromatography.

significant fraction of core enzyme. The $\sigma$ factor may have been partly lost from the polymerase during the isolation and purification. In addition, it has been shown that only 0.3 to $0.4 \mathrm{~mol}$ of $\sigma$ are present in vivo in $E$. coli per mol of core polymerase (Burgess, 1976). The situation may be similar in the case of $R$. leguminosarum 300 .

RNA polymerase preparations from $E$. coli have often been found to contain a small polypeptide, named 'omega', of unknown function (molecular weight 9000 to 12000 ; Burgess, 1976). Such a polypeptide was not detected in fractions 41 to 55 of the Bio-Gel A5m column by SDS-PAGE on $15 \%$ gels, even though the $\omega$ polypeptide of the $E$. coli RNA polymerase was demonstrated on the same gel (not shown). An $\omega$ polypeptide was also absent from the RNA polymerase of $A$. tumefaciens (Knopf, 1974).

\section{Properties of the purified enzyme}

RNA polymerase activity, assayed with pMB9 DNA as template, was dependent on the presence of divalent cations, maximum activity occurring at 2.5 to $5.0 \mathrm{mM} \mathrm{MgCl}$. Therefore, all further in vitro assays with the RNA polymerase from $R$. leguminosarum 300 were performed in the presence of $5 \mathrm{mM}-\mathrm{MgCl}_{2}$.

The temperature optimum was between 30 and $35^{\circ} \mathrm{C}$. There was a linear increase in activity between 20 and $30^{\circ} \mathrm{C}$ by a factor of $2 \cdot 6$. All further in vitro assays with this RNA polymerase were done at $34^{\circ} \mathrm{C}$. Rhizobia are soil bacteria and generally grow best between 25 and $30^{\circ} \mathrm{C}$ (Vincent, 1970). This is also the temperature range for optimal growth of the related genus of Agrobacterium (Beiderbeck, 1977). The relatively high temperature $\left(41^{\circ} \mathrm{C}\right.$; 


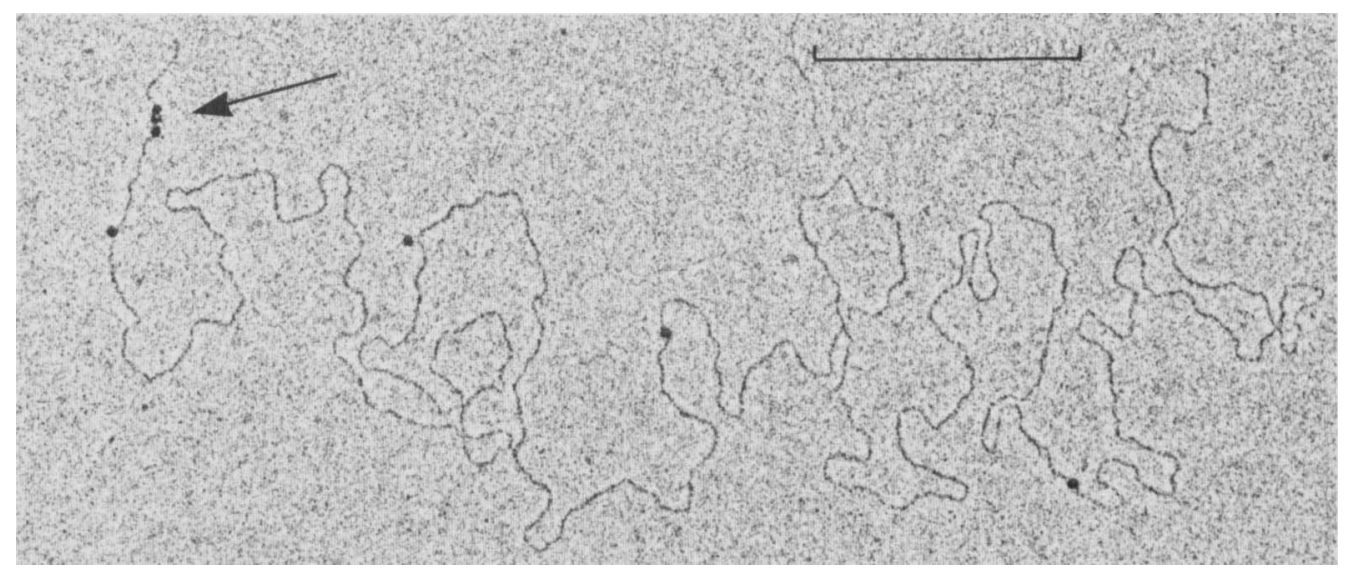

Fig. 5. Electron micrograph of a complex between the RNA polymerase holoenzyme from $R$. leguminosarum 300 and T7 DNA. Three molecules of RNA polymerase (arrowed) are bound close to one end of the DNA filament. The bar marker represents $0.5 \mu \mathrm{m}$.

Knopf, 1974) for maximal in vitro activity of the RNA polymerase from $A$. tumefaciens was therefore unexpected. We assume that the difference in apparent temperature optima for the RNA polymerases from $R$. leguminosarum 300 and $A$. tumefaciens are due to differences in the in vitro assay condtions (e.g. salt concentrations and types of templates used).

The time course of in vitro RNA synthesis catalysed by the RNA polymerase from $R$. leguminosarum 300 was studied over a period of $30 \mathrm{~min}$ using pSA31 as a DNA template. The incorporation of $\left[{ }^{3} \mathrm{H}\right]$ UMP into trichloroacetic acid-precipitable material was linear with time for at least $25 \mathrm{~min}$. A linear increase in radioactivity in trichloroacetic acid-precipitable material was also obtained with increasing RNA polymerase concentration (up to $15 \mu \mathrm{g}$ per $100 \mu$ assay), indicating that the enzyme preparation was free of major inhibitors of RNA synthesis.

\section{Promoter-specific DNA binding of the RNA polymerase}

Only the holoenzyme, not the $\sigma$-free core enzyme, of the $E$. coli RNA polymerase can bind selectively to promoter sites of a DNA template (for review, see Chamberlin, 1976). If polypeptide A corresponded to the $\sigma$ factor of the $R$. leguminosarum 300 RNA polymerase, we expected the enzyme to recognize promoter sequences. Since Rhizobium-specific promoters have not been described, we used purified DNA of $E$. coli phage T7, which has four RNA polymerase binding sites in the early promoter region at its left-hand end (Portmann et al., 1974; Koller et al., 1978).

The RNA polymerase of $R$. leguminosarum 300 bound to this region of the T7 genome (Fig. 5). The frequency of RNA polymerase molecules attached at given positions along the T7 DNA was determined quantitatively by computer analysis. The profile (Fig. 6) shows that the major peak of the RNA polymerase binding frequency is within the left $2 \%$ of the T7 DNA molecule. A similar distribution was obtained with $E$. coli RNA polymerase (not shown). The peak of RNA polymerase binding (Fig. 6) was not resolved further; in the case of the $E$. coli enzyme, four separate sub-peaks can be demonstrated if special experimental conditions are chosen (Koller et al., 1978).

The small peak of RNA polymerase binding at the right-hand side of the T7 genome (Fig. 6 ) is located at about $92 \%$ of the total molecule length. It may correspond to the peak VII of binding sites for $E$. coli RNA polymerase (Koller et al., 1978), determined at $92.5 \%$ (Delius et al., 1973). We conclude that the RNA polymerase from $R$. leguminosarum 300 can bind selectively to $E$. coli-specific promoter sites. 


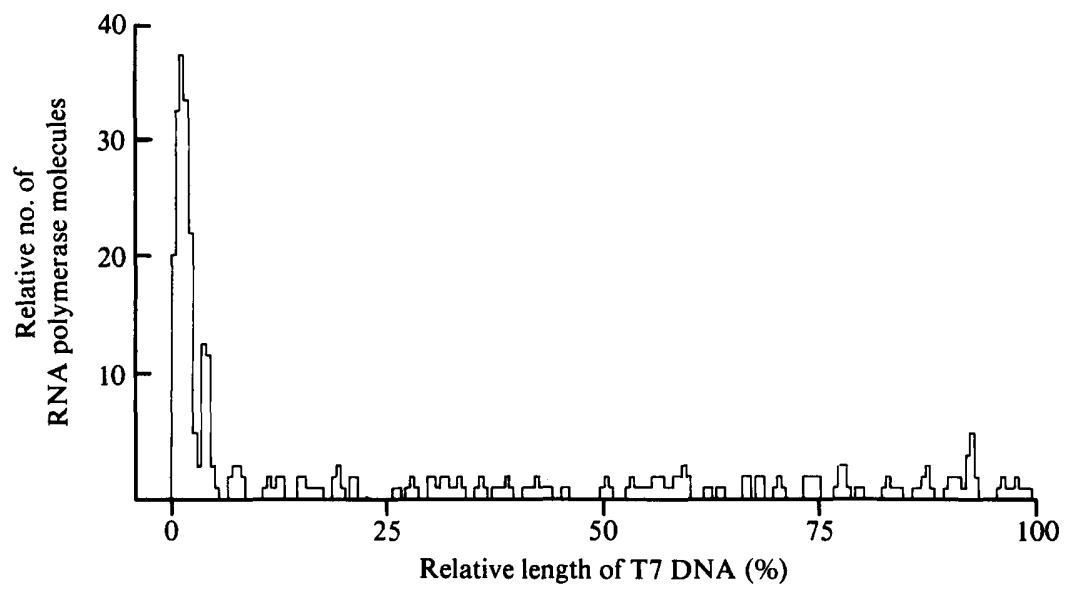

Fig. 6. Histogram of $R$. leguminosarum 300 RNA polymerase molecules bound to T7 DNA. The left-hand side of the histogram corresponds to the left side of the genetic map of bacteriophage T7. A total of $60 \mathrm{~T} 7$ molecules with bound RNA polymerase were analysed.

Wiggs et al. (1979) have shown that the early promoters of bacteriophage T7 can be utilized for the initiation of transcription by RNA polymerases of a great variety of bacterial orders and suggested that 'some common element in promoter sites remains conserved in all bacteria'. Although promoter sequences from the genus $R$ hizobium have not been described, the binding of $R$. leguminosarum RNA polymerase to the T7 promoters supports this hypothesis and is consistent with the expression of the $\operatorname{trp}$ genes of $E$. coli (localized on the broad host range plasmid RP4) in $R$. leguminosarum 300 (Nagahari et al., 1979). In addition, a cell-free 'coupled' transcription/translation system from $R$. leguminosarum 300 synthesized colicin E1 when the E. coli-specific ColE1 plasmid was added as a template (Laue-Schuler \& Lotz, unpublished results).

We are indebted to K. Pfleiderer for excellent technical assistance and to Dr J. E. Beringer for helpful comments and a critical reading of the manuscript. We thank Dr R. Lurz for providing T7 phage DNA, Professor E. Schweizer for providing the fermenter facilities and $\mathrm{Dr}$ K. Werkmeister for giving advice on inoculation and growth of large batch cultures. This work was supported by the Deutsche Forschungsgemeinschaft (Lo 149/7 and Lo 149/8).

\section{REFERENCES}

ARndT-Jovin, D. J., Jovin, T. M., BÄHR, W., Frischauf, A. M. \& MARQuardT, M. (1975). Covalent attachment of DNA to agarose. Improved synthesis and use in affinity chromatography. European Journal of Biochemistry 54, 411-418.

BeIDERBECK, R. (1977). Pflanzentumoren. Stuttgart: Ulmer.

Benveniste, R. \& Davies, J. (1973). Mechanisms of antibiotic resistance in bacteria. Annual Review of Biochemistry 42, 471-506.

Berg, D., BARretT, K. \& Chamberlin, M. (1971). Purification of two forms of Escherichia coli RNA polymerase and of sigma component. Methods in Enzymology 21D, 506-519.

BERINGER, J. E. (1974). R factor transfer in Rhizobium leguminosarum. Journal of General Microbiology 84, 188-198.

Burgess, R. R. (1969a). A new method for the large scale purification of Escherichia coli deoxyribonucleic acid-dependent ribonucleic acid polymerase. Journal of Biological Chemistry 244, 6160-6167.

Burgess, R. R. (1969 b). Separation and characterization of the subunits of ribonucleic acid polymerase. Journal of Biological Chemistry 244, 6168-6176.

Burgess, R. R. (1976). Purification and physical properties of $E$. coli RNA polymerase. In $R N A$ Polymerase, pp. 69-100. Edited by R. Losick \& M. Chamberlin. New York: Cold Spring Harbor Laboratory.

Burgess, R. R. \& Jendrisak, J. J. (1975). A procedure for the rapid, large-scale purification of Escherichia coli DNA-dependent RNA polymerase involving Polymin $P$ precipitation and DNAcellulose chromatography. Biochemistry 14, 46344638.

Burkardt, H. J., PÜhler, A. \& Wohlleben, W. 
(1980). Adenine + thymine content of different genes located on the broad host range plasmid RP4. Journal of General Microbiology 117, 135-140.

Chamberlin, M. J. (1976) Interaction of RNA polymerase with the DNA template. In $R N A$ Polymerase, pp. 159-191. Edited by R. Losick \& M. Chamberlin. New York: Cold Spring Harbor Laboratory.

Delius, H., Westphal, H. \& Axelrod, N. (1973). Length measurements of RNA synthesized in vitro by Escherichia coli RNA polymerase. Journal of Molecular Biology 74, 677-687.

Dunker, A. K. \& Rueckert, R. R. (1969). Observations on molecular weight determinations on polyacrylamide gel. Journal of Biological Chemistry 244, 5074-5080.

Guerry, P., LeBlanc, D. J. \& Falkow, S. (1973). General method for the isolation of plasmid deoxyribonucleic acid. Journal of Bacteriology 116, 1064-1066.

JoHNSTON, A. W. B. \& BERINGER, J. E. (1975). Identification of the Rhizobium strains in pea root nodules using genetic markers. Journal of General Microbiology 87, 343-350.

KNOPF, U. C. (1974). The nucleoside triphosphateribonucleic acid nucleotidyltransferase (EC 2.7.7.6) of Agrobacterium tumefaciens (Smith and Townsend) Conn. Biochemical Journal 143, 511520.

Koller, Th., Kübler, O. Portmann, R. \& Sogo, J. M. (1978). High resolution physical mapping of specific binding sites of Escherichia coli RNA polymerase on the DNA of bacteriophage T7. Journal of Molecular Biology 120, 121-131.

LAEMMLI, U.K. (1970). Cleavage of structural proteins during the assembly of the head of bacteriophage T4. Nature, London 227, 680-685.

LinN, T., Losick, R. \& SONENSHein, A. L. (1975). Rifampin resistance mutation of Bacillus subtilis altering the electrophoretic mobility of the beta subunit of ribonucleic acid polymerase. Journal of Bacteriology 122, 1387-1390.

LOSICK, R. \& PERO, J. (1976). Regulatory subunits of RNA polymerase. In $R N A$ Polymerase, pp. 227246. Edited by R. Losick \& M. Chamberlin. New York: Cold Spring Harbor Laboratory.

Nagahari, K., Koshikawa, T, \& Sakaguchi, K. (1979). Expression of Escherichia coli tryptophan operon in Rhizobium leguminosarum. Molecular and General Genetics 171, 115-119.

PaIN, A. N. (1979). Symbiotic properties of antibiotic-resistant and auxotrophic mutants of
Rhizobium leguminosarum. Journal of Applied Bacteriology 47, 53-64.

Pankhurst, C. E. (1977). Symbiotic effectiveness of antibiotic-resistant mutants of fast- and slowgrowing strains of Rhizobium nodulating Lotus species. Canadian Journal of Microbiology 23, 1026-1033.

Portmann, R., Sogo, J. M., Koller, Th. \& Zillig, W. (1974). Binding sites of $E$. coli RNA polymerase on T7 DNA as determined by electron microscopy. FEBS Letters 45, 64-67.

Rabussay, D. \& Zillig, W. (1969). A rifampicin resistant RNA-polymerase from $E$. coli altered in the $\beta$ subunit. FEBS Letters 5, 104-106.

Rodriguez, R. L., Bolivar, F., Goodman, H. M., BOYER, H. W. \& BETLACH, M. C. (1976). Construction of new cloning vehicles. In Molecular Mechanisms in the Control of Gene Expression, pp. 471-477. Edited by D. P. Nierlich, W. J. Rutter \& C. F. Fox. New York: Academic Press.

Van Brussel, A. A. N., Planqué, K. \& Quispel, A. (1977). The wall of Rhizobium leguminosarum in bacteroid and free-living forms. Journal of General Microbiology 101, 51-56.

VINCENT, J. M. (1970). A Manual for the Practical Study of the Root-nodule Bacteria. Oxford \& Edinburgh: Blackwell Scientific Pulications.

VINCENT, J. M. (1977). Rhizobium: general microbiology. In A Treatise on Dinitrogen Fixation, Section III, Biology, pp. 277-366. Edited by R. W. F. Hardy \& W. S. Silver. New York: John Wiley.

WEBER, K. \& OSBORN, M. (1969). The reliability of molecular weight determinations by dodecyl sulfatepolyacrylamide gel electrophoresis. Journal of Biological Chemistry 244, 4406-4412.

Wiggs, J. L., Bush, J. W. \& Chamberlin, M. J. (1979). Utilization of promoter and terminator sites on bacteriophage T7 DNA by RNA polymerases from a variety of bacterial orders. Cell 16, 97-109.

Zillig, W., Fuchs, E., Palm, P., Rabussay, D. \& ZECHEL, K. $(1970 a)$. On the different subunits of DNA-dependent RNA polymerase from $E$. coli and their role in the complex function of the enzyme. In Lepetit Colloquium on RNA Polymerase and Transscription, vol. 1, pp. 151-157. Edited by L. Silvestri. Amsterdam: North Holland.

Zillig, W., Zechel, K. \& Halbwachs, H. J. $(1970 b)$. A new method of large scale preparation of highly purified DNA-dependent RNA-polymerase from E. coli. Hoppe-Seyler's Zeitschrift für physiologische Chemie 351, 221-224. 